\title{
Recurrent ovary cancer presenting with scleroderma - a rare case report
}

\author{
Betul Sargin ${ }^{1}$, Gulcan Gurer ${ }^{1}$, Gulnur Tasci Bozbas², Fatih Noyan ${ }^{2}$, Kayra Barut ${ }^{2}$, Canten \\ Tataroglu $^{3}$
}

\begin{abstract}
Scleroderma is a chronic autoimmune multisystem disorder which is characterized by progressive fibrosis of the skin and internal organs. Ovary cancers with scleroderma have been reported in the literature. But recurrent ovary cancer with scleroderma has not been reported before. Here, we report a 65 -year old female patient presenting with recurrent ovary cancer and subsequently diagnosed with scleroderma. To the authors' knowledge, this is the first case of presenting with recurrent ovary cancer and scleroderma.
\end{abstract}

Keywords: recurrent, ovary cancer, scleroderma

\section{Introduction}

Scleroderma is a chronic autoimmune multisystem disorder which is characterized by progressive fibrosis of the skin and internal organs (1).This disorder develops in the 30-50s and occurs with the average incidence up to $0.002 \%$ (2). There are 3 subclasses of systemic scleroderma: limited cutaneous, diffuse cutaneous and sine scleroderma. Prognosis depends on the extent of organ involvement (3). Cutaneous associations of ovarian carcinoma are rare manifestations. These include acanthosis nigricans, Raynaud's phenomenon, scleroderma, dermatomyositis and palmar fasciitis with polyarthritis (4), disseminated superficial porokeratosis (5), multicentric reticulohistiocytosis (MR) (6) and leukocytoclastic vasculitis (7) . Here, we report a 65 year old female patient presenting with recurrent ovary cancer and subsequently diagnosed with scleroderma. In scanning literature, it was seen that recurrent ovary cancer and scleroderma has not been reported yet.

\section{Case}

A 65-year old female patient presented with complaints of diffuse cutaneous sclerosis and thickening along with oedema in right lower limp since four months (Figure 1). She had a history of a serous papillary adenocarcinoma of the ovary. This was diagnosed 4 years prior to her presentation to our clinic and she had been treated adjuvant chemotherapy; paclitaxel and carboplatin. She underwent total abdominal hysterectomy (TAH) with bilateral salpingo-oophorectomy (BSO) and pelvic lymph node dissection.
She had responded well to her treatment. On further questioning, she had noticed thickening and oedema in right lower limp. She did not have medical history about Raynaud's phenomenon, sclerodactylia, pitting scars before. She had no history of smoke or alcohol consumption. The general condition was moderate, oriented and cooperated. Locomotor system examination revealed there was skin thickening in right lower limp. The patient's laboratory findings are presented in Table 1. Doppler ultrasonography was normal. A skin biopsy was taken and the histology showed dermal sclerosis pathology was consistent with scleroderma (Figure 2). Due to the presence of dermal biopsy, acute-phase proteins including erythrocyte sedimentation rate, C-reactive protein and immunological tests including antinuclear antibody were investigated. These tests showed positive antinuclear antibody (ANA) (1 : >100 granular and nuclear membrane), anti-Scl 70 antibody $(2+)$. She was subsequently found to have an elevated carcinoma antigen 125 level of 190 units/ml and the patient was diagnosed as recurrent ovary cancer and scleroderma. Computed tomography (CT) of the chest, abdominal cavity and pelvis were normal with no metastases. She was started on prednisolone (32 mg) and hydroxychloroquine (200 mg) while her subsequent examinations took place. She was later started on paclitaxel chemotherapy for recurrent ovary cancer and until now has received two cycles. Following prednisolone and hydroxychloroquine treatment, her complaints of skin thickening and oedema in right lower limp were improved.

Received 21-10-2017 Accepted 15-11-2017 Available Online 30-11-2017

1 Adnan Menderes University, Medical Faculty, Dept of Physical Medicine and Rehabilitation, Rheumatology, Aydın , TR

2 Adnan Menderes University, Medical Faculty, Dept of Physical Medicine and Rehabilitation, Aydın, TR

3 Adnan Menderes University, Medical Faculty, Dept of Pathology, Aydın, TR

* Corresponding Author: Betul Sargin E-mail: betul.cakir@yahoo.com Phone: +90 2562136064 
Table 1. Laboratory findings of the patient

\begin{tabular}{lll}
\hline & Values & Normal Range \\
\hline Hemoglobin & $13,3 \mathrm{gr} / \mathrm{dl}$ & $11,7-15,5 \mathrm{gr} / \mathrm{dl}$ \\
Hematocrit & $40,4 \%$ & $37-44$ \\
Leukocyte count & $6,63 \mathrm{mkrl}$ & $3,800-11,000 \mathrm{mkrl}$ \\
Platelet & $216,000 \mathrm{mkrl}$ & $150,000-350,000 \mathrm{mkrl}$ \\
Erythrocyte sedimentation rate & $48 \mathrm{~mm} / \mathrm{h}$ & $0-20 \mathrm{~mm} / \mathrm{h}$ \\
C-reactive protein & $14,81 \mathrm{mg} / \mathrm{l}$ & $0-6 \mathrm{mg} / \mathrm{l}$ \\
Urea & $27 \mathrm{gr} / \mathrm{dl}$ & $13-43 \mathrm{gr} / \mathrm{dl}$ \\
Creatinine & $0,80 \mathrm{mg} / \mathrm{dl}$ & $0,7-1,3 \mathrm{mg} / \mathrm{dl}$ \\
ANA & $1:>100$ granular and nuclear & Negative \\
Anti- -Scl 70 & membrane pattern & \\
\hline
\end{tabular}

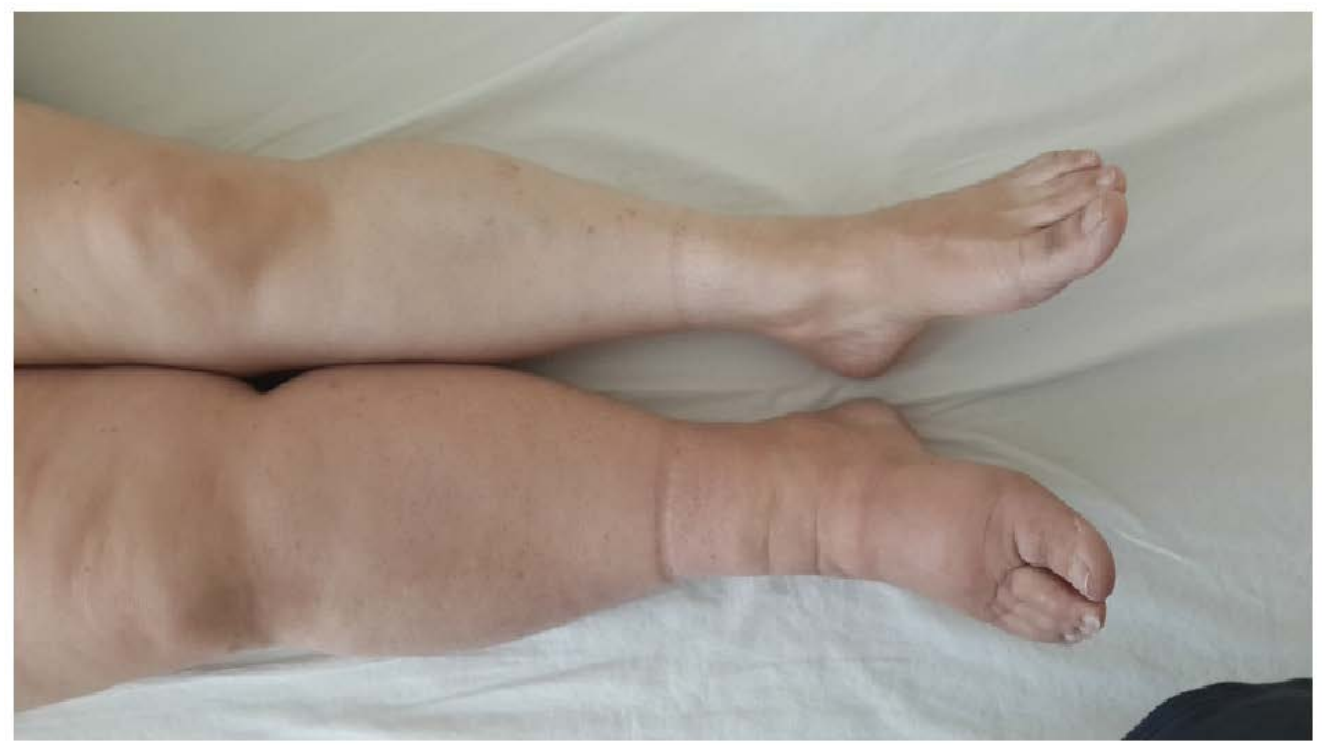

Figure 1: Right limp oedeme

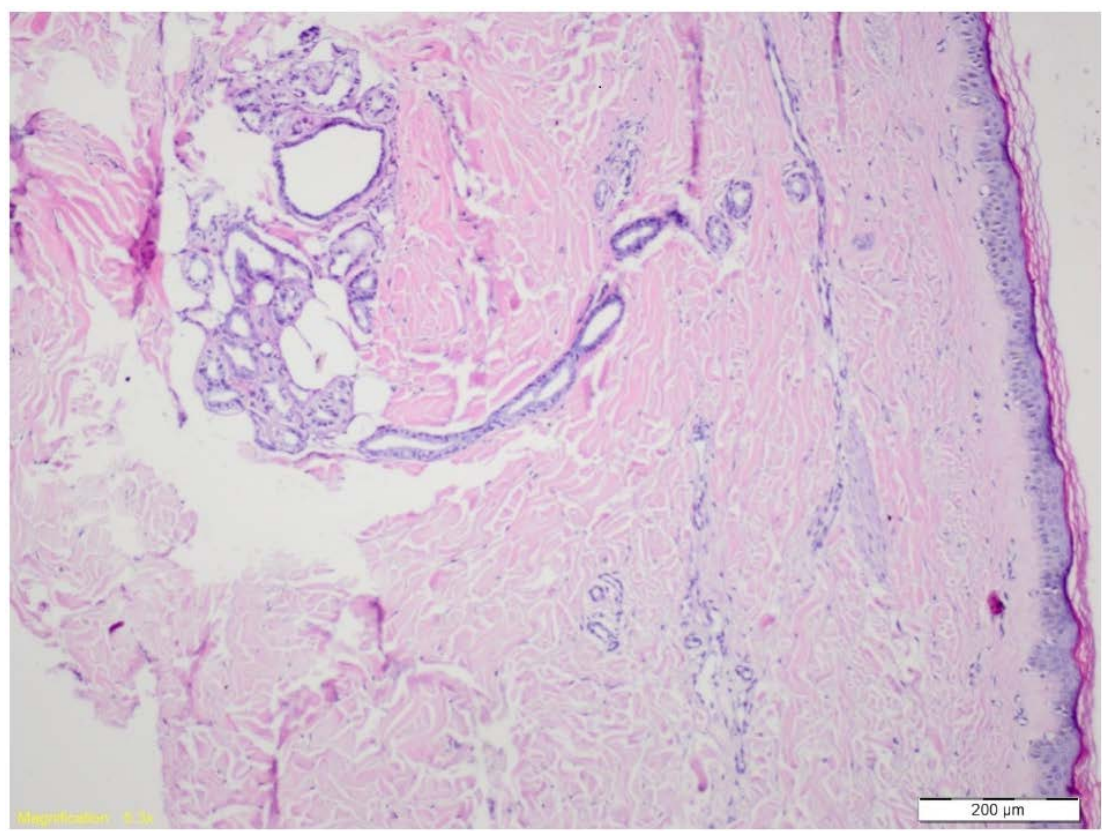

Figure 2: Dermal edema, perivascular lymphocyte infiltration and collagen fibriler hyperplasia 


\section{Discussion}

To the knowledge, this is the first case of recurrent ovary cancer presenting with scleroderma. Jedlickova et al. indicated 4 patients with paraneoplastic scleroderma who were diagnosed with cholangiogenic carcinoma, endometrial carcinoma, prostatic adenocarcinoma and adenoma of the suprarenal gland (8). Marek et al. noticed a case with scleroderma-like syndrome in the course of colorectal cancer (2). Several studies have suggested an increased risk of cancer in patients with systemic sclerosis, but the potential risk factors for these cancers remain unknown. Kyndt et al. announced among 123 patients with systemic sclerosis, 14 cases of cancer $(11.3 \%)$ were found (lung $n=3$, breast $n=2$, ovarian $n=2$, skin $n=1$, thyroid $n=1$, rectum $n=1$, uterine cervix $\mathrm{n}=1$, larynx $\mathrm{n}=1$, pancreas $\mathrm{n}=1$, myelodysplasia $\mathrm{n}$ = 1) (9). Bielefeld et al. reported 21 cases of the association systemic scleroderma and cancer. (lung $n=$ 5 , breast $\mathrm{n}=2$, oesophagus $\mathrm{n}=1$, stomach $\mathrm{n}=$ 1 , colon $n=1$, uterus $n=4$, ovarian $n=1$, prostatic $n$ $=1$, renal $\mathrm{n}=1$ and malignant hemopathies $\mathrm{n}=6$ ). Bielefeld et al. stated that since 1886, more than three hundred cases of such an association have been reported; essentially lung cancers (more than 100) and epidemiological studies concluded a higher frequency of lung and breast cancers (10). In the literature, we found 27 case-reports exposing the co-existence systemic scleroderma and cancer after this review. Case reports about association of scleroderma and ovary cancer are available in literature (11-16). Su et al. presented a 53-year-old woman with systemic sclerosis and Meigs' syndrome (pleural effusion, ascites and an ovarian tumour) (17). In scanning literature, co- existence of scleroderma and ovary cancers were presented, although recurrent ovary cancer that were presented with scleroderma has not been reported. Also, case reports developing cancer after scleroderma diagnoses were informed. But, recurrent cancer development presenting with scleroderma as in our case is not common. Reynolds et al. announced a 44-year-old woman with a history of recurrent metastatic breast cancer presenting with paraneoplastic scleroderma (18). Findings of our patient didn't supported paraneoplastic scleroderma. Because, a serous papillary adenocarcinoma started for 4 years ago, her laboratory analysis showed antiScl 70 antibody positive and she responded good to standard treatment. In the literature, our patient is second case recurrent cancer presenting with scleroderma. Moreover, our patient is first case recurrent ovary cancer presenting with scleroderma.

\section{Conclusion}

We suggest that cutaneous associations of ovarian cancer or other other malignities should be carefully followed until a final diagnosis can be clearly made. When cutanouse lesion develops in patients who have cancer history, the possibility of recurrent cancer should be kept in mind and the patients should be examined in this respect.

Acknowledgments: This prospective study was performed at Sehitkamil Goverment Hospital, Gaziantep, Turkey

Conflict of Interest: The authors declare no potential conflicts of interest with respect to the research, authorship, and/or publication of this article.

Author's Contributions: Concept - G.G.; Design B.S.; Supervision - G.G.; Materials - C.T.; Data Collection and / or Processing - F.N ., K.B ; Analysis and / or Interpretation - G.G.; Literature Review B.S.; Writing - B.S., G.G.; Critical Review - G.G.; Other - C.T.

Ethical issues: All Authors declare that Originality of research/article etc... and ethical approval of research, and responsibilities of research against local ethics commission are under the Authors responsibilities. The study was conducted due to defined rules by the Local Ethics Commission guidelines and audits.

\section{References}

1. Kotnur MR, Suresh P, Reddy VS , Sharma T, Salim NA .Systemic Sclerosis with Multiple Pulmonary Manifestations. J Clin Diagn Res [Internet]. 2016 June ;10(6):OD16-7. Available from: http://www.ncbi.nlm.nih.gov/pubmed/4963699.

2. Marek M, Rudny R .Scleroderma of geriatric age and scleroderma-like paraneoplastic syndrome - description of two cases. Reumatologia [Internet]. 2016 June;54(2):91-4. Available from: http://www.ncbi.nlm.nih.gov/pubmed/ 4918051

3. Lachner KD. Caring for the Patient With Limited Systemic Scleroderma. Orthop Nurs. [Internet].2016 JanFeb;35(1):5-10; quiz 11-2.Available from: http://www.ncbi.nlm.nih.gov/pubmed/ 26814000.

4. Scheinfeld N. A review of the cutaneous paraneoplastic associations and metastatic presentations of ovarian carcinoma. Clin Exp Dermatol. [Internet]. 2008 Jan ;33(1):10-5. Available from: http://www.ncbi.nlm.nih.gov/pubmed/ 17983453.

5. Cannavó SP, Borgia F, Adamo B, Guarneri B. J .Simultaneous development and parallel course of disseminated superficial porokeratosis and ovarian cancer: Coincidental association or true paraneoplastic syndrome? Am Acad Dermatol. [Internet]. 2008 Apr;58(4):657-60. Available from: http://www.ncbi.nlm.nih.gov/pubmed/ 18258333. 
6. Kishikawa T, Miyashita T, Fujiwara E, Shimomura O, Yasuhi I, Niino D, et al .Multicentric reticulohistiocytosis associated with ovarian cancer. Mod Rheumatol. [Internet].2007;17(5):422-5.Available from: http://www.ncbi.nlm.nih.gov/pubmed/ 17929137.

7. Stashower ME, Rennie TA, Turiansky GW, Gilliland WR Ovarian cancer presenting as leukocytoclastic vasculitis. J Am Acad Dermatol. [Internet].1999 Feb ;40(2 Pt 2):287-9. Available from: http://www.ncbi.nlm.nih.gov/pubmed/ 10025849 .

8. Jedlickova H, Durčanská V, Vašků V. Paraneoplastic Scleroderma: Are There Any Clues? Acta Dermatovenerol Croat. [Internet]. 2016 Apr ;24(1):78-80. Available from: http://www.ncbi.nlm.nih.gov/pubmed/ 27149136.

9. Kyndt X , Hebbar M, Queyrel V, Hachulla E, Hatron PY, Devulder B. Systemic scleroderma and cancer. Search for predictive factors of cancer in 123 patients with scleroderma. Rev Med Interne. [Internet]. 1997 Jul;18(7):528-32. Available from: http://www.ncbi.nlm.nih.gov/pubmed/ 9255370.

10. Bielefeld P , Meyer P, Caillot D, Dalac S, Camus P, Tavernier C, et al. Systemic scleroderma and cancers: 21 cases and review of the literature. Rev Med .[Internet]. 1996 Jan;17(10):810-3. Available from: http://www.ncbi.nlm.nih.gov/pubmed/ 8976973.

11. Kawakami Y, Nakamura $\mathrm{K}$, Nakamura-Wakatsuki $\mathrm{T}$, Ohtsuka M, Oyama N, Kaneko F. Systemic sclerosis complicated by ovarian cancer. J Dermatol. [Internet]. 2007 Oct;34(10):720-3. Available from: http://www.ncbi.nlm.nih.gov/pubmed/ 17908147.

12. Vottery R, Biswas G, Deshmukh C, Gupta S, Nair R, Parikh P. Scleroderma and dermographism in a case of carcinoma ovary. Indian J Dermatol Venereol Leprol. [Internet].2005 Nov ;71(6):429-30. Available from: http : // www . ncbi . nlm .nih.gov/pubmed/ 16394490.
13. Eisenbeilss C, Weizel J, Wolff H. Scleroderma-like skin changes following administration of paclitaxel for the treatment of ovarian carcinoma. J Dtsch Dermatol Ges. [Internet]. 2003 Jun;1(6):468-70. Available from: http : // www . ncbi . nlm .nih.gov/pubmed/ 16295141.

14. De Angelis R, Bugatti L, Cerioni A, Del Medico P, Filosa G. Diffuse scleroderma occurring after the use of paclitaxel for ovarian cancer. [Internet] Clin Rheumatol. 2003 Feb;22(1):49-52. Available from: http : // www . ncbi . nlm .nih.gov/pubmed/ 12605319.

15. Young R, Towbin B, Isern R. Scleroderma and ovarian carcinoma. $\mathrm{Br} \quad \mathrm{J}$ Rheumatol. [Internet].1990 Aug;29(4):314. Available from: http : // www . ncbi . nlm .nih.gov/pubmed/ 2379051.

16. Konishi Y, Sato H, Sato N, Fujimoto T, Fukuda J, Tanaka T.Scleroderma- like cutaneous lesions induced by paclitaxel and carboplatin for ovarian carcinoma, not a single course of carboplatin, but re induced and worsened by previously administrated paclitaxel. J Obstet Gynaecol Res. [Internet]. 2010 Jun;36(3):693-6. Available from: http : // www . ncbi . nlm .nih.gov/pubmed/ 20598060.

17. Su F , Cummings KW, Krigman H, Ranganathan P.Meigs' syndrome: a rare cause of recurrent pleural effusion in scleroderma. Rheumatol Int. [Internet].2013 Oct ;33(10):2647-51. Available from: http : // www . ncbi . nlm .nih.gov/pubmed/ 22538500.

18. Reynolds TD , Knights SE. Recurrent metastatic breast cancer presenting with paraneoplastic scleroderma. [Internet]. BMJ Case Rep. 2014 Mar 11;2014. Available from: http : // www . ncbi . nlm .nih.gov/pubmed/ 24618872. 